\section{Scientific journal}

\section{PHYSICAL AND MATHEMATICAL EDUCATION}

Has been issued since 2013.

Науковий журнал

ФІЗИКО-МАТЕМАТИЧНА ОСВІТА

Видається з 2013.
ISSN 2413-158X (online)

ISSN 2413-1571 (print)

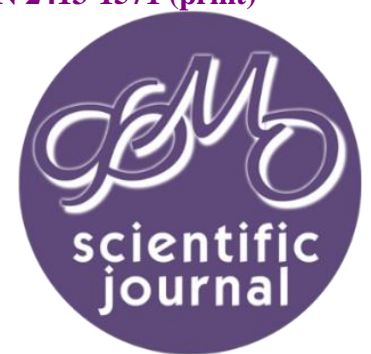

Дущенко О.С. Сучасний стан цифрової трансформації освіти. Фізико-математична освіта. 2021. Випуск 2(28). C. 40-45.

Dushchenko O. Current state of digital transformation of education. Physical and Mathematical Education. 2021. Issue 2(28). P. 40-45.

DOI 10.31110/2413-1571-2021-028-2-007
удк $37+004$

О.С. Дущенко

Ізмаїльський державний гуманітарний університет, Україна olyanichi@gmail.com ORCID: 0000-0002-7934-0299

\title{
СУЧАСНИЙ СТАН ЦИФРОВОЇ ТРАНСФОРМАЦІЇ ОСВІТИ
}

\begin{abstract}
АНОТАЦІЯ
Формулювання проблеми. Суспільство знаходиться на етапі використання найсучасніших технологій у різних напрямах з різноманітними потребами: від використання роботів, 3D-друку у медицині, технологій обробки великих обсягів даних, хмарних і безпаперових технологій на підприємствах, технологій в освіті (організація цифрових університетів), квантових технологій, штучного інтелекту, роботів у розробці техніки до використання інтернет речей у повсякденному житті тощо. Таке використання цифрових технологій вимагає, щоб майбутні випускники знали та вміли користуватися ними. Якраз у Концепції розвитку цифрової економіки та суспільства України на 2018-2020 роки наголошено про необхідність цифровізації освіти. А цифровізація передбачає використання цифрових технологій. Відповідно наразі виникає запитання "Якою зараз є цифрова трансформація освіти?», "Чи досягнуто поставлені завдання концепції на практиці?».

Матеріали і методи. Аналіз наукових праць щодо стану цифрової трансформації освіти України, систематизація отриманих результатів, пояснення сучасного стану цифрової трансформації освіти.

Результати. Проведений аналіз наукових праць, надав можливість схарактеризувати ключові поняття, визначити цифрові технології як найсучасніші технології, які поєднують використання технологій (великих обсягів даних, хмарного середовища, інтернет речей, роботизації, итучного інтелекту, квантових технологій тощо) і мережі Інтернет, гаджетів, сучасних ПК, а цифровізацію - використання цифрових технологій; цифрову трансформацію. Окреслено напрями цифровізації освіти. Схарактеризовано сучасний стан цифрової трансформації освіти. Виділено існуючі проблеми цифрової трансформації освіти.

Висновки. Використання цифрових технологій в освітньому процесі забезпечує підготовку спеціалістів до конкурентоспроможності у сучасному світовому суспільстві. Але необхідним є вирішення існуючих проблем цифрової трансрормації освіти.
\end{abstract}

КлЮчОвІ СлОвА: цифровізація, цифрова трансформація, цифрові технології, цифровий університет, цифрова компетентність.

\section{ВСТУП}

Постановка проблеми. У світі сучасних технологій освітня сфера потребує активного впровадження цих технологій в освітній процес. Так, у Концепції розвитку цифрової економіки та суспільства України на 2018-2020 роки зазначено, що першочерговими завданнями $€$ формування ґрунтової національної політики цифровізації освіти як пріоритетної складової частини реформи освіти, визначено конкретні ініціативи підключення класів до широкосмугового Інтернету, створення та реалізація сучасних моделей забезпечення учнів та навчальних закладів комп'ютерними засобами, підготовка, адаптація та організація доступу до мультимедійних технологій та створення відповідних цифрових освітянських платформ для використання в освітньому процесі та управління освітою (Концепція розвитку цифрової економіки та суспільства України на 2018-2020 роки). Основною метою цієї концепції $€$ «реалізація ініціатив «Цифрового порядку денного України 2020» (Цифрова адженда України-2020) (Про схвалення Концепції розвитку цифрової економіки та суспільства України на 2018-2020 роки та затвердження плану заходів щодо ії реалізації). А у Цифровій адженді України2020 (Проєкт «Цифрова адженда України - 2020) зазначено, що основними завдання у державному освітянському сегменті у частині професійних цифрових навичок (програмування тощо) $€$ «впровадження підходу з урахуванням наскрізної (кросплатформової) цифрової компетентності (вивчення предметів з використанням цифрових технологій);

(C) О.С. Дущенко, 2021. 
збільшення частки та підвищення якості підготовки ІКТ-спеціалістів, упровадження програм профорієнтації до роботи в IKT-сфері; розробка системи «соціального ліфту» в ІКТ-сфері (проходження стажувань, практики в IKT-компаніях); оновлення державного класифікатору професій (зокрема «цифрових» професій). Отже, бачимо, що пріоритетним $\epsilon$ використання цифрових технологій в освітньому процесі з метою підготовки ІКТ-спеціалістів. Одразу виникають запитання «Що таке поняття «цифрової трансформації освіти?», «як реалізується ця трансформація?».

Аналіз останніх досліджень. Вивчення наукових праць учених показало, що питання цифрової трансформації освіти знаходиться в полі зору вчених. Зокрема, В. Ю. Биков виділяє проблеми розвитку і впровадження цифрових технологій в освіту, пропонує заходи для цифрової трансформації освіти; О. П. Буйницька, Л. О. Варченко-Троценко, Б. І. Грицеляк аналізують цифровізацію закладу вищої освіти, виокремлюють компоненти цифрового кампусу, етапи його впровадження, систематизують міжнародний досвід запровадження цифрового кампусу, наводять порівняльний аналіз існуючих рішень за кордоном; С. О. Карплюк розглядає особливості цифровізації освітнього процесу у вищій школі; С. Г. Литвинова досліджує ініціативи та впровадження цифровізації закладів загальної середньої освіти; Н. В. Морзе, В. П. Вембер, М.А. Гладун вивчають 3D картування цифрової компетентності в системі освіти України; В. В.Сухонос, Ю. В. Гаруст, Я.А. Шевцов розглядають діджиталізацію освіти в Україні; В.М. Бабаєв, Г. В. Стадник, Т. В. Момот систематизують стратегічні орієнтири розвитку ІКТ та «цифровізації» в Україні, визначають тренди в сфері цифрових технологій тощо. Але питання сучасного стану цифрової трансформації освіти не досліджено.

Мета статті. Поставимо за мету проаналізувати поняття «цифрова трансформація освіти», систематизувати досвід учених щодо використання цифрових технологій в освітньому процесі, описати сучасний стан цифрової трансформації освіти.

\section{МЕТОДИ ДОСЛІДЖЕННЯ}

Використовуються такі методи дослідження, як аналіз наукових праць щодо тлумачення ключових понять, систематизація інформації щодо використання цифрових технологій в освіті, напрямів цифровізації освіти, пояснення сучасного стану цифрової трансформації освіти.

\section{РЕЗУЛЬТАТИ ДОСЛІДЖЕННЯ ТА ЇХ ОБГОВОРЕННЯ}

Відповідно до Концепції розвитку цифрової економіки та суспільства України на 2018-2020 роки цифрова трансформація сучасної повної загальної середньої освіти полягає у використанні цифрових технологій: «від комп'ютерних класів до цифрових технологій у кожному учнівському портфелі, кожному класі, у кожного вчителя, на кожній парті» (Концепція розвитку цифрової економіки та суспільства України на 2018-2020 роки). Цифрові технології повинні використовуватися на кожному уроці, при взаємодії учасників освітнього процесу, реалізації індивідуального процесу тощо, тобто мати багатоплатформенний наскрізний характер. А цифрова освіта визначається як "об'єднання різних компонентів і найсучасніших технологій завдяки використанню цифрових платформ, упровадження нових інформаційних та освітніх технологій, застосуванню прогресивних форм організації освітнього процесу та активних методів навчання, а також сучасних навчально-методичних матеріалів» (Концепція розвитку цифрової економіки та суспільства України на 2018-2020 роки).

У контексті дослідження використовується поняття «цифровізація», тому з'ясуємо, що означає це поняття. Так, цифровізація - «насичення фізичного світу електронно-цифровими пристроями, засобами, системами та налагодження електронно-комунікаційного обміну між ними, що фактично уможливлює інтегральну взаємодію віртуального та фізичного, тобто створює кіберфізичний простір» (Концепція розвитку цифрової економіки та суспільства України на 20182020 роки). Цифровізація (з англ. digitalization) - це впровадження цифрових технологій (інтернет речей, роботизація та кіберсистеми, штучний інтелект, великі дані, безпаперові технології, адитивні технології (3D-друк), хмарні та туманні обчислення, безпілотні та мобільні технології, біометричні, квантові технології, технології ідентифікації, блокчейн тощо (Україна 2030Е - країна з розвинутою цифровою економікою) в усі сфери життя: від взаємодії між людьми до промислових виробництв, від предметів побуту до дитячих іграшок, одягу тощо. Це перехід біологічних та фізичних систем у кібербіологічні та кіберфізичні (об'єднання фізичних та обчислювальних компонентів). Перехід діяльності з реального світу у світ віртуальний (онлайн) (Україна 2030Е - країна з розвинутою цифровою економікою). До речі, В. Ю. Биков зазначає, що терміни «інформаційно-комунікаційні технології», «електронні технології», «цифрові технології» слід використовувати як синоніми (Биков, 2017). Натомість цифрова трансформація (цифровізація) - це перетворення наявних аналогових (іноді електронних) продуктів, процесів та бізнес-моделей організації, у основі якої лежить ефективне використання цифрових технологій (Україна 2030Е - країна з розвинутою цифровою економікою). Отже, бачимо, що цифровізація є цифровою трансформацією.

Розглянемо думки вчених щодо цифрової трансформації освіти. На думку В. Ю. Бикова, «цифрова трансформація суспільства відображає тенденції розвитку науково-технічного прогресу в ІКТ-сфері, серед яких основними є: забезпечення мобільності ІК-діяльності користувачів у інформаційних просторах; розвиток технологій хмарних обчислень та IKT-інфаструктур; накопичення та опрацювання значних обсягів цифрових даних з метою прийняття обґрунтованих рішень; розвиток інтернет людей; формування інтернету речей; розвиток систем електронних комунікацій - розгортання мереж 3G, 4G і 5G; розвиток робототехніки; розвиток систем захисту даних; забезпечення сумісності IKT-засобів та IKTдодатків; розвиток мереж постачальників IKT-послуг, ринку IKT-аутсорсерів (Биков, 2017).

Натомість С. Г. Литвинова визначає цифрову трансформацію освітнього процесу як «насичення фізичного простору освітньої установи електронно-цифровими пристроями, засобами, системами та впровадження педагогічних технологій на засадах використання інформаційно-комунікаційних, хмарно орієнтованих технологій та технологій доповненої й віртуальної реальностей» (Сучасні тенденції розвитку інформаційно-комунікаційних технологій в освіті, 2020).

Визначено у яких напрямах повинна відбуватись цифровізація освіти. Відповідно до Концепції розвитку цифрової економіки та суспільства України на 2018-2020 роки до основних напрямів цифровізації освіти відносяться: створення 
освітянських ресурсів і цифрових платформ з підтримкою інтерактивного та мультимедійного контентів для загального доступу закладів освіти та учнів, зокрема інструментів автоматизації головних процесів роботи закладів освіти; розроблення та впровадження інноваційних комп'ютерних, мультимедійних та комп'ютерно орієнтованих засобів навчання та обладнання для створення цифрового освітнього середовища (мультимедійні класи науково-дослідних STEMцентрів, лабораторії, інклюзивні класи, класи змішаного навчання); організація широкосмугового доступу до Інтернету учнів та студентів у навчальних класах та аудиторіях у закладах освіти всіх рівнів; розвиток дистанційної форми освіти з використанням когнітивних та мультимедійних технологій (Концепція розвитку цифрової економіки та суспільства України на 2018-2020 роки).

У Цифровій адженді України-2020 (Проєкт «Цифрова адженда України - 2020) зазначено, що «цифровізація» закладів загальної середньої освіти повинна реалізовуватись у таких напрямах: доступ до технологій (учнів, учителів, адміністрації школи), шкільний Інтернет; «цифровий» мультимедійний контент; «цифрові» компетенції та грамотність викладачів (фасилітаторів, коучів), учнів.

Дослідниця С.Г.Литвинова виділяє основні напрями цифрової трансформації освітнього процесу закладів загальної середньої освіти: формування цифрового освітнього середовища закладів освіти (подолання цифрового розриву і гейміфікації); використання хмарних технологій для навчання учнів (забезпечення повсюдного доступу й онлайнова освіта); розвиток STEM освіти (проєктний підхід); використання комп'ютерного моделювання для цифрової трансформації навчання; використання доповненої реальності для цифрової трансформації підручників; розвиток e-skills учителів для цифрової трансформації (Сучасні тенденції розвитку інформаційно-комунікаційних технологій в освіті, 2020). На думку вченої, світовими освітніми трендами інформаційно-цифрової трансформації $€$ хмарні обчислення, робототехніка, цифрова комунікація, інтернет речей тощо (Литвинова, 2019). Авторка виділяє такі проблеми процесів цифровізації освітнього процесу: відсутність підключення до Інтернету у більшості кабінетів; відсутність і не унормованість використання е-щоденників, е-журналів, е-документообігу; залучення системних адміністраторів для підтримки освітнього процесу з використанням IKT; оновлення нормативної бази щодо списання комп'ютерів, комп'ютерних програм (Литвинова, 2019).

Учені (В. М. Бабаєв, Г.В.Стадник, Т.В.Момот) зазначають, що розвиток цифрових технологій та збільшення попиту на вищу освіту стимулює створення нового типу університетів: мега університетів і мережі університетів без кордонів (Бабаєв, 2019). У свою чергу, деякі дослідники (В. В. Сухоноса, Ю. В. Гаруста, Я. А. Шевцова) уважають, що «вищим рівнем діджиталізації освіти є створення окремих онлайн-університетів» (Сухонос, 2019). Автори зазначають, що в США початкова і середня освіта не обмежені лише навчальною програмою, оскільки у навчальних закладах отримувати додаткову освіту можливо засобами цифрових технологій в якості онлайн-курсів, з ухвали викладачів (Сухонос, 2019).

На основі міжнародного досвіду вчені (В. М. Бабаєв, Г. В. Стадник, Т. В. Момот) підкреслюють, що найдоцільнішим $€$ змішане навчання із використанням різних форм навчання для підвищення якості освіти (Бабаєв, 2019). А інші вчені (В.В.Сухонос, Ю.В.Гаруст, Я.А.Шевцов), аналізуючи зарубіжний досвід, роблять висновок про необхідність діджиталізації освіти, виділяючи такі переваги: «інноваційність (нові можливості для всіх суб'єктів освітнього процесу), модернізація освіти (перехід на новий якісний рівень), доступність (онлайн-школи та університети, доступні кожному, по всьому світу, у будь-який час, які забезпечать якісною освітою кожного), сприятливість інтеграційним процесам та світовому процесу глобалізації (у випадку України це сприяння європейській інтеграції) (Сухонос, 2019).

Дослідники (О. П. Буйницька, Л.О.Варченко-Троценко, Б.І.Грицеляк) пропонують використовувати поняття «цифровий університет» або «цифровий кампус», визначаючи його як університет, "у якому всі учасники освітнього процесу отримують персоналізовані дані про ресурси, пристрої, аудиторії для ефективнішого виконання завдань» (Буйницька\&Варченко-Троценко\&Грицеляк, 2020). Учені виділяють сценарії реалізації цифрового університету: використання віртуальної і доповненої реальностей при презентації закладу; використання штучного інтелекту для відповідей на онлайн-запити; запровадження електронного навчання (з використанням адаптивних технологій); використання електронного документообігу; інтелектуальні системи прийняття рішень; використання штучного інтелекту для управління ресурсами закладу тощо (Буйницька\&Варченко-Троценко\&Грицеляк, 2020). Автори аналізують можливості платформ для створення цифрового кампусу, зокрема Campus on Cloud, LMS 365, Classter, TESLA EDU, SMART\&LMS, ZEROBIT SMART CAMPUS, EXAMUS, виділяючи Classter як найоптимальніший варіант (Буйницька\&ВарченкоТроценко\&Грицеляк, 2020).

На думку С. О. Карплюк, «розвиток Інтернету і мобільних комунікацій є базовими технологіями цифровізації» (Карплюк, 2019). Цифрова трансформація передбачає «упровадження більш гнучких процесів, зміну корпоративної культури, оптимізацію процесів» (Карплюк, 2019).

Отже, цифровізація - використання цифрових технологій. А цифрові технології - найсучасніші технології, які поєднують використання технологій (великих обсягів даних, хмарного середовища, інтернет речей, роботизації, штучного інтелекту, квантових технологій тощо) і мережі Інтернет, гаджетів, сучасних ПК.

Учений В. Ю. Биков підкреслює, що «програмно-апаратну основу цифрової трансформації суспільства закладе конвергенція найсучасніших нано-, біо-, інформаційних, когнітивних технологій - НВІК-технології (англ., NBIC Technologies), базових технологій суспільства знань, а користувально-технологічну основу - світова мережа Центрів опрацювання даних, що побудовані на базі хмаро орієнтованої віртуалізованої ІКТ-інфраструктури, та персональні електронні комунікатори» (Биков, 2017). Під персональним електронним комунікатором розуміється «портативний, компактний, зручний і безпечний у застосуванні мобільним користувачем бездротовий електронний цифровий пристрій, у якому суміщені функції смартфонів, кишенькових персональних комп'ютерів і контролерів, а також засобів радіочастотних ідентифікацій та GPS-позиціювання» (Биков, 2017). Отже, бачимо, що підтверджується наша думка щодо цифрових технологій як найсучасніших технологій.

У Цифровій адженді України-2020 (Проєкт «Цифрова адженда України - 2020) зазначено, що через стрімке розповсюдження цифрових технологій ключовими стають цифрові навички (компетенції). Представлено piвні DQ (Digital 
Quotient) (Проєкт «Цифрова адженда України - 2020) навичків щодо цифрових технологій, а саме: «цифрове громадянство» (використання цифрових технологій у повсякденному житті), «цифрова творчість» (використання цифрових технологій для створення контенту, медіа, застосувань тощо), «цифрове підприємництво» (використання цифрових технологій у різних сферах діяльності).

Учені використовують поняття «цифрова компетенція». Так, дослідники (І. Бородкіна, Г. Бородкін) визначають цифрову компетенцію як «здатність користувача впевнено, ефективно та безпечно вибирати і застосовувати інформаційні та комунікаційні технології в різних сферах життя, заснована на безперервному оволодінні новими знаннями та вміннями» (Бородкіна\&Бородкін, 2018).

Автори (І. Бородкіна, Г. Бородкін) виділяють модель цифрової компетенції студентів, опис якої наводять у вигляді переліку знань, умінь, навичок, які використовуються при оцінюванні рівня цифрової компетенції студентів: інформаційний менеджмент (пошук, перегляд, оцінювання, збереження і відтворення інформації), спілкування в цифрових середовищах (спілкування за допомогою цифрових засобів, поширення інформації та контенту, громадянська активність у мережі Інтернет, співпраця за підтримки цифрових технологій, мережний етикет, адміністрування цифрової ідентичності), цифровий контент на творчість (створення нового знання, авторське право і захист інтелектуальної власності, програмування), безпека (захист обладнання, персональних даних, здоров'я і навколишнього середовища), вирішення проблем (рішення технічних проблем, з'ясування потреб і пошук шляхів для їх вирішення, творче використання інновацій і технологій, самооцінювання цифрової компетенції) (Бородкіна\&Бородкін, 2018).

Отже, залишається актуальним як покращити рівень цифрової трансформації освіти. I відповідь на це $\epsilon$ думки вчених (пропозиції) відповідно до дій на рівні держави.

\section{ВИСНОВКИ ТА ПЕРСПЕКТИВИ ПОДАЛЬШОГО ДОСЛІДЖЕННЯ}

Таким чином, цифрова трансформація освіти передбачає активне впровадження цифрових технологій в освітній процес. Сучасний стан цифрової трансформації освіти вимагає продовження впровадження використання цифрових технологій, адже, наразі не всі заклади освіти (зокрема, заклади загальної середньої освіти) мають підключення до мережі Інтернет чи відповідне сучасне комп'ютерне оснащення. Відповідно питання впровадження цифрових технологій стає неможливим. Тому, у першу чергу, вимагається вирішення цих питань державою для подальшої цифрової трансформації освіти. Наразі відбувається створення освітніх ресурсів особливо в умовах пандемії, цифрових платформ з підтримкою освітнього контенту, створення цифрового освітнього контенту (особливо закладами вищої освіти), організація доступу до мережі Інтернет закладами вищої освіти, розвиток цифрової компетентності науково-педагогічних працівників. Отже, необхідно виправляти існуючі проблеми та продовжувати використання цифрових технологій в освітніх закладах.

Перспективи подальших розробок убачаємо у продовженні вивчення питання цифрової трансформації освіти особливо в аспекті розвитку і появи нових цифрових технологій.

\section{Список використаних джерел}

1. Бабаєв В. М., Стадник Г. В., Момот Т. В. Цифрова трансформація в сфері вищої освіти в умовах глобалізації. Комунальне господарство міст. Серія : Економічні науки. 2019. Вип. 2. С. 2-9. URL: http://nbuv.gov.ua/UJRN/kgm_econ_2019_2_3 (Дата звернення 11.12.2020).

2. Биков В.Ю. Суспільство знань і освіта 4.0. Освіта для майбутнього у світлі викликів XXI століття (польська, EDUKACJA W KONTEKŚCIE ZMIAN CYWILIZACYJNYCH). BydgoszCz : Widawnictwo Uniwersytetu Kazimierza Wielkiego, 2017. C. 30-45. URL: https://lib.iitta.gov.ua/708567/1/\%D0\%91\%D0\%B8\%D0\%BA\%D0\%BE\%D0\%B2\%20\%D0\%92_\%D1\%81\%D1\%82\%D0\%B0\%D1 \%82\%D1\%82\%D1\%8F2017.pdf (Дата звернення 11.12.2020).

3. Биков В. Ю. Цифрова трансформація суспільства і розвиток комп'ютерно-технологічної платформи освіти і науки України. Інформаційно-цифровий освітній простір України: трансформаційні процеси і перспективи розвитку: методологічний семінар НАПН України (м. Київ, 4 квітня 2019 р.), 2019. С. 20-26.

4. Бородкіна І., Бородкін Г. Модель цифрової компетенції студентів. Цифрова платформа : інформаційні технології в соціокультурній сфері. 2018. Вип. 1. С. 27-41. URL: http://nbuv.gov.ua/UJRN/dpitsca_2018_1_4 (Дата звернення 10.12.2020).

5. Буйницька О. П., Варченко-Троценко Л. О., Грицеляк Б. І. Цифровізація закладу вищої освіти. Освітологічний дискурс : електронне наукове фахове видання. 2020. № 1 (28). С. 64-79.

6. Карплюк С. О. Особливості цифровізації освітнього процесу у вищій школі. Інформаційно-цифровий освітній простір України: трансформаційні процеси і перспективи розвитку : методологічний семінар НАПН України (м. Київ, 4 квітня 2019 р.), 2019. С. 188-197.

7. Концепції розвитку цифрової економіки та суспільства України на 2018-2020 роки. URL: https://zakon.rada.gov.ua/laws/show/67-2018-\%D1\%80\#n13 (Дата звернення 09.12.2020).

8. Литвинова С.Г. Інформатизація і цифровізація загальної середньої освіти: ініціативи й освітнє впровадження. Інформаційно-цифровий освітній простір України: трансформаційні процеси і перспективи розвитку : методологічний семінар НАПН України (м. Київ, 4 квітня 2019 р.), 2019. С. 130-137.

9. Морзе Н. В., Вембер В. П., Гладун М. А. 3D картування цифрової компетентності в системі освіти України. Інформаційні технології і засоби навчання. 2019. Том 70 (2). С. 28-42.

10. Про схвалення Концепції розвитку цифрової економіки та суспільства України на 2018-2020 роки та затвердження плану заходів щодо ії реалізації. URL: https://www.kmu.gov.ua/npas/pro-shvalennya-koncepciyi-rozvitku-cifrovoyiekonomiki-ta-suspilstva-ukrayini-na-20182020-roki-ta-zatverdzhennya-planu-zahodiv-shodo-yiyi-realizaciyi (Дата звернення 09.12.2020). 
11. Проєкт «Цифрова адженда України - 2020». URL: https://ucci.org.ua/uploads/files/58e78ee3c3922.pdf (Дата звернення 09.12.2020).

12. Сухонос В. В., Гаруст Ю. В., Шевцов Я. А. Діджиталізація освіти в Україні: зарубіжний досвід та вітчизняна перспектива впровадження. Правові горизонти. 2019. Вип. 19 (32). С. 79-86.

13. Сучасні тенденції розвитку інформаційно-комунікаційних технологій в освіті : зб. матеріалів ІІ Міжнародної науковопрактичної конференції в рамках Міжнародного освітнього форуму «Цифрова трансформація освіти». Рівне : РОІППО, 2020. 78 c.

14. Україна 2030E - країна з розвинутою цифровою економікою. URL: https://strategy.uifuture.org/kraina-z-rozvinutoyucifrovoyu-ekonomikoyu.html (Дата звернення 09.12.2020).

\section{References}

1. Babaiev, V. M. \& Stadnyk, H. V. \& Momot, T. V. (2019). Tsyfrova transformatsiia v sferi vyshchoi osvity v umovakh hlobalizatsii [Digital transformation in higher education in the context of globalization]. Komunalne hospodarstvo mist. Seriia: Ekonomichni nauky, 2, 2-9. Retrieved from http://nbuv.gov.ua/UJRN/kgm_econ_2019_2_3 [in Ukrainian].

2. Bykov, V. Iu. (2017). Suspilstvo znan i osvita 4.0 [Knowledge Society and Education 4.0]. Osvita dlia maibutnoho u svitli vyklykiv KhKhl stolittia (polska, EDUKACJA W KONTEKŚCIE ZMIAN CYWILIZACYJNYCH). Bydgoszcz : Widawnictwo Uniwersytetu Kazimierza Wielkiego, 30-45. Retrieved from https://lib.iitta.gov.ua/708567/1/\%D0\%91\%D0\%B8\%D0\%BA\%D0\%BE\%D0\%B2\%20\%D0\%92_\%D1\%81\%D1\%82\%D0\%B0\%D1 \%82\%D1\%82\%D1\%8F2017.pdf [in Ukrainian].

3. Bykov, V. Yu. (2019). Tsyfrova transformatsiia suspilstva i rozvytok kompiuterno-tekhnolohichnoi platformy osvity i nauky Ukrainy [Digital transformation of society and development of computer-technological platform of education and science of Ukraine]. Informatsiino-tsyfrovyi osvitnii prostir Ukrainy: transformatsiini protsesy i perspektyvy rozvytku. Proceedings of the methodological seminar of the National Academy of Pedagogical Sciences of Ukraine. (pp. 20-26). Kiev [in Ukrainian].

4. Borodkina, I. \& Borodkin, H. (2018). Model tsyfrovoi kompetentsii studentiv [Model of digital competence of students]. Tsyfrova platforma : informatsiini tekhnolohii $v$ sotsiokulturnii sferi, 1, 27-41. Retrieved from http://nbuv.gov.ua/UJRN/dpitsca_2018_1_4 [in Ukrainian].

5. Buinytska, O. P. \& Varchenko-Trotsenko, L. O. \& Hrytseliak, B. I. (2020). Tsyfrovizatsiia zakladu vyshchoi osvity [Digitization of higher education institutions]. Osvitolohichnyi dyskurs : elektronne naukove fakhove vydannia, 1 (28), 64-79 [in Ukrainian].

6. Karpliuk, S. O. (2019). Osoblyvosti tsyfrovizatsii osvitnoho protsesu u vyshchii shkoli [Features of digitalization of the educational process in higher education]. Informatsiino-tsyfrovyi osvitnii prostir Ukrainy: transformatsiini protsesy i perspektyvy rozvytku. Proceedings of the methodological seminar of the National Academy of Pedagogical Sciences of Ukraine. (pp. 188-197). Kiev [in Ukrainian].

7. Kontseptsii rozvytku tsyfrovoi ekonomiky ta suspilstva Ukrainy na 2018-2020 roky [Concepts of development of digital economy and society of Ukraine for 2018-2020]. zakon.rada.gov.ua. Retrieved from https://zakon.rada.gov.ua/laws/show/67-2018-\%D1\%80\#n13 [in Ukrainian].

8. Lytvynova, S. H. (2019). Informatyzatsiia i tsyfrovizatsiia zahalnoi serednoi osvity: initsiatyvy y osvitnie vprovadzhennia [Informatization and digitalization of general secondary education: initiatives and educational implementation]. Informatsiino-tsyfrovyi osvitnii prostir Ukrainy: transformatsiini protsesy i perspektyvy rozvytku. Proceedings of the methodological seminar of the National Academy of Pedagogical Sciences of Ukraine. (pp. 130-137). Kiev [in Ukrainian].

9. Morze, N. V. \& Vember, V. P. \& Hladun, M. A. (2019). 3D kartuvannia tsyfrovoi kompetentnosti v systemi osvity Ukrainy [3D mapping of digital competence in the education system of Ukraine]. Informatsiini tekhnolohii i zasoby navchannia, 70 (2), 2842 [in Ukrainian].

10. Pro skhvalennia Kontseptsii rozvytku tsyfrovoi ekonomiky ta suspilstva Ukrainy na 2018-2020 roky ta zatverdzhennia planu zakhodiv shchodo yii realizatsii [On approval of the Concept of development of the digital economy and society of Ukraine for 2018-2020 and approval of the action plan for its implementation]. www.kmu.gov.ua. Retrieved from https://www.kmu.gov.ua/npas/pro-shvalennya-koncepciyi-rozvitku-cifrovoyi-ekonomiki-ta-suspilstva-ukrayini-na20182020-roki-ta-zatverdzhennya-planu-zahodiv-shodo-yiyi-realizaciyi [in Ukrainian].

11. Proiekt "Tsyfrova adzhenda Ukrainy - 2020» [Project "Digital Agenda of Ukraine - 2020"]. ucci.org.ua. Retrieved from https://ucci.org.ua/uploads/files/58e78ee3c3922.pdf [in Ukrainian].

12. Sukhonos, V. V. \& Harust, Yu. V. \& Shevtsov, Ya. A. (2019). Didzhytalizatsiia osvity v Ukraini: zarubizhnyi dosvid ta vitchyzniana perspektyva vprovadzhennia [Digitalization of education in Ukraine: foreign experience and domestic prospects for implementation]. Pravovi horyzonty, 19 (32), 79-86 [in Ukrainian].

13. Suchasni tendentsii rozvytku informatsiino-komunikatsiinykh tekhnolohii v osviti (2020). [Current trends in the development of information and communication technologies in education]. Proceedings of the II International scientific-practical conference within the framework of the International educational forum "Digital transformation of education". Rivne : ROIPPO, 78 [in Ukrainian].

14. Ukraina 2030E - kraina z rozvynutoiu tsyfrovoiu ekonomikoiu [Ukraine $2030 \mathrm{E}$ is a country with a developed digital economy]. strategy.uifuture.org. Retrieved from https://strategy.uifuture.org/kraina-z-rozvinutoyu-cifrovoyu-ekonomikoyu.html [in Ukrainian]. 


\section{CURRENT STATE OF DIGITAL TRANSFORMATION OF EDUCATION}

Olha Dushchenko

Abstract.

Izmail State University of Humanities, Ukraine

Formulation of the problem. Society is at the stage of using the latest technologies in various fields with different needs: from the use of robots, 3D printing in medicine, large data processing technologies, cloud and paperless technologies in enterprises, technologies in education (digital universities), quantum technologies, artificial intelligence, robots in the development of technology for the use of the Internet of Things in everyday life, etc. Such use of digital technologies requires that future graduates know and be able to use them. The Concept of Development of the Digital Economy and Society of Ukraine for 2018-2020 emphasizes the need for digitalization of education. And digitalization involves the use of digital technologies. Accordingly, the question now arises: "What is the current digital transformation of education?", "Have the objectives of the concept been achieved in practice?".

Materials and methods. Analysis of scientific works on the state of digital transformation of education in Ukraine, systematization of the results, explanation of the current state of digital transformation of education.

Results. The analysis of scientific works provided an opportunity to characterize key concepts, identify digital technologies as the most modern technologies that combine the use of technology (large amounts of data, cloud environment, Internet of Things, robotics, artificial intelligence, quantum technology, etc.) and the Internet, gadgets, modern PCs, and digitalization - the use of digital technologies; digital transformation. The directions of digitalization of education are outlined. The current state of digital transformation of education is characterized. The existing problems of digital transformation of education are highlighted.

Conclusions. The use of digital technologies in the educational process provides training for competitiveness in today's world society. But it is necessary to solve the existing problems of digital transformation of education.

Key words: digitalization; digital transformation; digital technologies; digital university; digital competence. 